International Journal of Agriculture and Environmental Research

ISSN: 2455-6939

Volume: 07, Issue: 06 "November-December 2021"

\title{
CLIMATE CHANGE AND FARM SIZE IN CENTRAL KOGI STATE, NIGERIA: THE PERCEPTION OF SMALL-SCALE FARMERS
}

\author{
${ }^{1}$ Assitan DAOU, ${ }^{2}$ J. M. BABA, ${ }^{2}$ A. A. OKHIMAME, ${ }^{3}$ S. IBRAHIM, ${ }^{4}$ A. D. AKPA \\ ${ }^{1}$ Department of West African Science Service Center on Climate Change and Adapted Land Use \\ (WASCAL CC \& ALU), Federal University of Technology, Minna, Nigeria. \\ ${ }^{2}$ Department of Geography, Federal University of Technology, Minna, Niger State, Nigeria. \\ ${ }^{3}$ Department of Agriculture, Federal University of Technology, Minna, Niger State, Nigeria. \\ ${ }^{4}$ Agricultural Development Project, Kogi State, Nigeria. \\ DOI: https://doi.org/10.51193/IJAER.2021.7612
}

Received: 11 Dec. 2017 / Accepted: 18 Dec. 2017 / Published: 01 Jan. 2022

\begin{abstract}
Rainfall is becoming more unpredictable and unreliable both in its timing and volume and growing seasons are changing, ecological zones are shifting. Therefore, this study was conducted to find out the impact of climate change on agricultural land use in Kogi State. For this purpose, rainfall and temperature data from NIMET and questionnaire on farmer's perception were used. Binary Logit Model was used to determine factor that influence farmer size. Results show a slight increase in both temperature and rainfall up to 0.4 and 0.10 respectively. Lowest and highest temperatures were recorded in 1989 and 2005 respectively with values of $27.3^{\circ} \mathrm{C}$ and $29.2^{\circ} \mathrm{C}$. In terms of adaptation strategies, seven (7) adaptation strategies were employed by farmers, viz: changing planting dates, implement soil conservation schemes and change crop variety at $31 \%, 22 \%$ and $21 \%$ respectively in response to change in rainfall. Logit regression model reveals that change in rainfall patterns $($ Fpr. $=0.122)$ has no significant impact on farmers' decision to change farm size at 5\% level of significance. However, number of family member schooling (Fpr. $=0.01)$, household farming experience $($ Fpr. $=0.00)$ and access to credit $($ Fpr. $=0.00)$ have significant impact on farmers' decision to change farm size.
\end{abstract}

Keywords: Climate Change, Rainfall, Temperature, Farm size, Small-scale Farmers. 
International Journal of Agriculture and Environmental Research

ISSN: 2455-6939

Volume: 07, Issue: 06 "November-December 2021"

\section{INTRODUCTION}

Agriculture plays an important role on the environment in the process of providing employment and source of livelihood for the increasing population (Aigbokhan, 2001; Onyeahialam, 2002). The sector accounts for about 40 percent of Gross Domestic Product (GDP) and provides employment, both formal and informal, for about 60 percent of Nigerians (Olagunju, 2007; Odoemelam, 2011). Climate is the first determinant of agricultural productivity. Given the fundamental role of agriculture in human welfare, concern has been expressed by federal agencies and others regarding the potential effects of climate change on agricultural productivity (Apata, et al., 2009). Interest in this issue has motivated a substantial body of research on climate change and agriculture over the past decade (Lobell et al., 2008; Fischer et al., 2002).

According to World Bank (2008) 75\% of the world's poor live in rural areas in developing countries and most of them depend on agriculture for their livelihoods. Increased rainfall could result in water-logged soils unsuitable for agriculture. This would lead to soil erosion and loss of soil nutrients important for plant growth, hence the effect of climate change may reduce agricultural land use due to submergence of coastal regions and increased aridity in the tropical high agricultural regions (Ngaira, 2007). Regarding the fundamental role of agriculture as a main source of income for about $80 \%$ of the population (NBS, 2006) in the study area (Kogi State) and the challenges that farmers are facing due to the adverse effect of climate change. Therefore, this study was carried out in areas whereby agriculture is highly dependent on rainfall agriculture, especially in those areas where there is no much information about the climate change issue with the following objective: analyze rainfall and temperature, investigate the perception of farmers to climate and determine factors that affect farmers' adaption to climate change.

Climate change is a global challenge that has a particularly strong effect on most developing countries, where adaptive capacity is low and where agriculture, which is highly dependent on climatic factors, is the main source of income for the majority of people. Faced with the various risks of climate variability (drought, winds, crops insects and pests, etc.), farmers have developed adaptation strategies. Adaptation to climate change is one of the approaches considered likely to reduce the impacts of long-term changes in climate variables. It is a process by which strategies to moderate and cope with the consequences of climate change, including climate variability, can be enhanced, developed and implemented (Oksen, 2000). Adaptation is a decision making. Farmers continuously have to make choices about what to plant, how to plant, when to plant. Together, these decisions influence what type of farming system the farmer in question establishes. Decisions that farmers make depend on the natural, cultural and economic conditions but also the climate such as the availability of the rainfall (McCalla, 1998). In the tropics and precisely in West Africa, major agro-ecological zones are arid, semi-arid, sub-humid, and humid. 


\section{International Journal of Agriculture and Environmental Research}

ISSN: 2455-6939

Volume: 07, Issue: 06 "November-December 2021"

There is, in general, a strong relationship between agro-climatic conditions and cropping systems. Animal grazing systems also differ between arid, semi-arid, humid areas (McCalla, 1998).

To increase the yield farmers practice mixed farming or agro-pastoralism. "Mixing farming, combining crop and livestock activities, holds considerable promise for meeting criteria of environmental sustainability and of improved productivity" (Oksen, 2000). Mixed farming has been viewed as the most promising means to increase the agriculture productivity of semi-arid West Africa (Turner, 1993 cited in Oksen, 2000) as animal would provide the traction power and the manure associated with the agriculture intensification. OECD (2009) reported that agropastoralism stems from a strategy adopted by farmers and shepherds to limit the risks associated with the uncertain climate. Farming helps shepherds limit the purchase of cereals during the lean period; farmers, on their part, seek to diversify their activities and capitalize on their income sources by investing in cattle.

The smallholder plantation farming system provides the farmer with a mix of food and cash crops that offer a large degree of self-sufficiency. Furthermore, the mix of trees offers almost complete protection to the soil, sustains the nutrient cycle, and eliminates the need for cultivation implicit in the production of annual food crops (Uchua, 2011). An increasing number of farmers rely on crops with shorter growing seasons and integrate indigenous trees and plants such as Annona muricata, Prunus africana and Pygeum africana in their food crop farms. The farmer's report that traditional technologies for conserving soil fertility, mixed cropping, and multiple cropping are aimed at buffering the farming system against climate variability and increasing farm yield and income (Molua, 2002). Ahenkan and Boon (2010) reported that Planting of economic trees and adopting sustainable farming systems had been identified as important coping strategies by a significant number of farmers in Western Ghana. Through capacity building and sensitization, most farmers have recognized the importance of planting economic trees on their farms to shade their crops.

Nyamadzawo et al. (2013) stated that to reduce the vulnerability to smallholder farmers in semi arid regions to climate change and variability, and to increase the resilience to climate change there is need to optimize in-field water harvesting techniques so as to improve crop yields. Infield water harvesting is one of the many climate change adaptation strategies that can be adopted by farmers in the semi- arid regions. It can potentially enhance soil water storage, and this will enable crops to survive during mid-season droughts. Improved water harvesting may result in improved crop yields, food security and livelihood among households. 
International Journal of Agriculture and Environmental Research

ISSN: 2455-6939

Volume: 07, Issue: 06 "November-December 2021"

\section{RESEARCH METHODOLOGY}

\section{Study area}

The study area is located in north central Nigeria within latitudes $6^{\circ} 30 \mathrm{~N}$ to $8^{\circ} 50 \mathrm{~N}$ and longitudes $5^{\circ} 20 \mathrm{E}$ to $8^{\circ} 00 \mathrm{E}$ (see Figure 1), which occupies $30,354.74 \mathrm{~km} 2$. Kogi State is the most centrally located of all the states of the federation (Ibitoye, 2006). The State was created out of Kwara and Benue States along with eight other states on the $27^{\text {th }}$ of August 1991. It has twenty one local government areas and is divided into three senatorial districts namely: Kogi East, Kogi Central and Kogi West. Kogi East comprises Ankpa, Bassa, Dekina, Ofu, Omala, Olamaboro, Ibaji, Idah and Igalamela-Odolu L.G.As. Kogi Central comprises: Ajaokuta, Okene, Okehi, Adavi and Ogori-mangogo LGAs, while Kogi West Comprises: Kabba-Bunnu, Ijumu, Lokoja, Kogi, Yagba-West, Yagba-East and Mopa-Amuro local government areas (LGAs). The population was 3,278,487 people in 2006, which comprised 1,691,736 males and 1,586,750 females (NPC, 2006). In Kogi State, 70 percent of the population resides in the rural area with about 80 percent being farmers (NBS, 2006). This population is made up of various ethnic groups, which include; Kigali (40.93\%), Yoruba (10.73\%), Nupe (4.85\%) and Bassa Komo (4.07\%) speaking people (Ibitoye, 2006).

The choice of Kogi State is based on the fact that, the State is among the major four food potential growing regions in Nigeria mainland; if these area is vulnerable to climate change and variation the growth of Nigeria economy may be impaired. Farming is the predominant occupation of the people of Kogi State. Mixed cropping is the predominant type of farming in the State (Ibitoye, 2006). The land use pattern is fallow-cropping system operated with hoes and cutlasses. After cultivating a piece of land for between 3 to 5 years, it is left to fallow for some years and the farmer shifts to a more fertile land. 


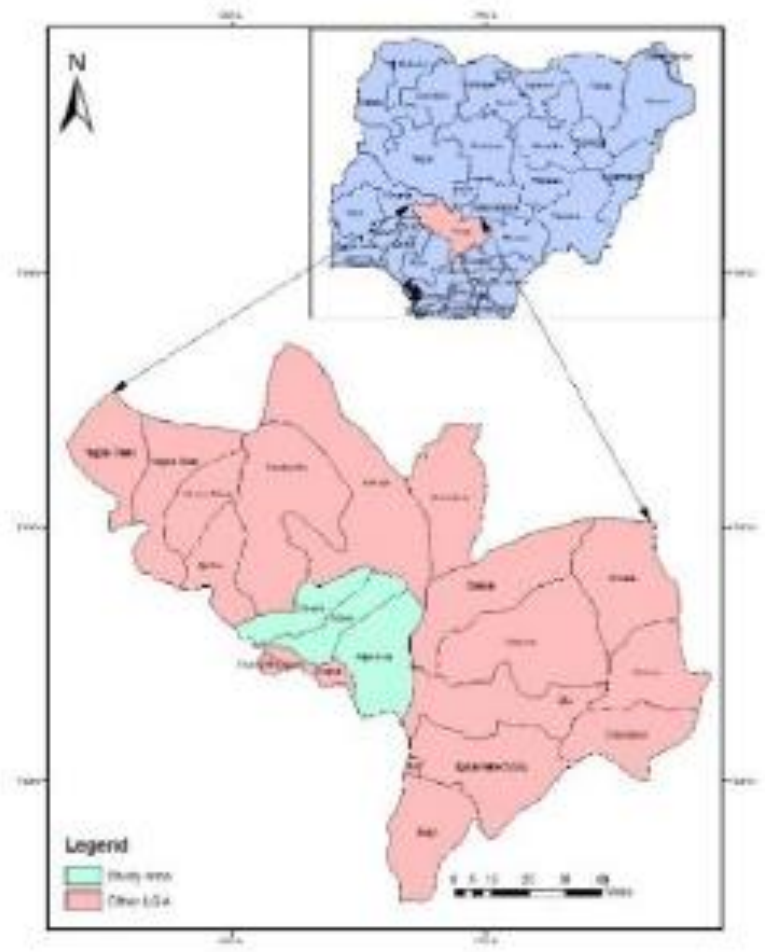

Figure 1: Location of the study area

Source: Author's data analysis, 2015

\section{Climate data collection}

Forty years (1975-2014) daily rainfall and temperature were collected from Nigerian Meteorological Agency NIMET).

\section{Sampling procedure}

The target people for this study were crop farmers. Multi-stage random sampling was used. From the study area, three local government areas were randomly selected. In each local government area, two villages were selected each making a total of six villages. The villages were Osaka and Aku in Adavi local government area; Adu and Ebiya in Ajaokuta local government area; Ihima and Ohoupe in Okehi local government area. Samples of forty farmers from each of the six villages were selected giving a total sample of 240 farmers in all. Structured interview was conducted on these respondents for data collection. A structured questionnaire comprising both open and close ended questions was written in English which was interpreted by resource persons from ADP into local dialect in order to acquire accurate information. The questionnaire contained in four (4) sections; Section A was on the demographic and socio-economic details, 
section $\mathrm{B}$ on agriculture land use, $\mathrm{C}$ on climate change and finally, D on strategies adopted to deal with climate change.

\section{RESULT AND DISCUSSION}

\section{Annual mean temperature}

Figure 2 presents the trend of annual mean temperature in the study area over the period of forty years (1975-2014) with fluctuation in the mean from year to year. The mean annual temperature was $27.43^{\circ} \mathrm{C}$ in 1975 which increased to $28.53^{\circ} \mathrm{c}$ in 2014 . The lowest and highest annual temperature is $27.3^{\circ} \mathrm{C}$ and $29.2^{\circ} \mathrm{C}$ respectively in 1989 and 2005 . The annual mean is $28.2^{\circ} \mathrm{c}$ with $0.44^{\circ} \mathrm{c}$ of standard deviation and $1.5 \%$ of coefficient of variation. This mean was similar with the mean by Audu (2012). The $\mathrm{R}^{2}=0.4$ reveals that the increase is not significant. This less than the global mean temperature with an increase of $0.74^{\circ} \mathrm{C}$ since recordings commenced in 1860 (IPCC, 2007; Spore, 2008). Hence, it is certain that the earth's temperature is rising. The steady rise in temperature across Nigeria is the cause of global warming. As confirmed by (Audu, 2012) that Global warming is the gradual, but continuous increase in temperature of an area over time. It is caused by both natural and man - made factors. Although, the current trend of global warming has indicated that man - made factors are the most critical factors which result from various activities aimed at making life more comfortable such as industrialization, intensive and extensive farming, use of generating sets and urbanization among others.

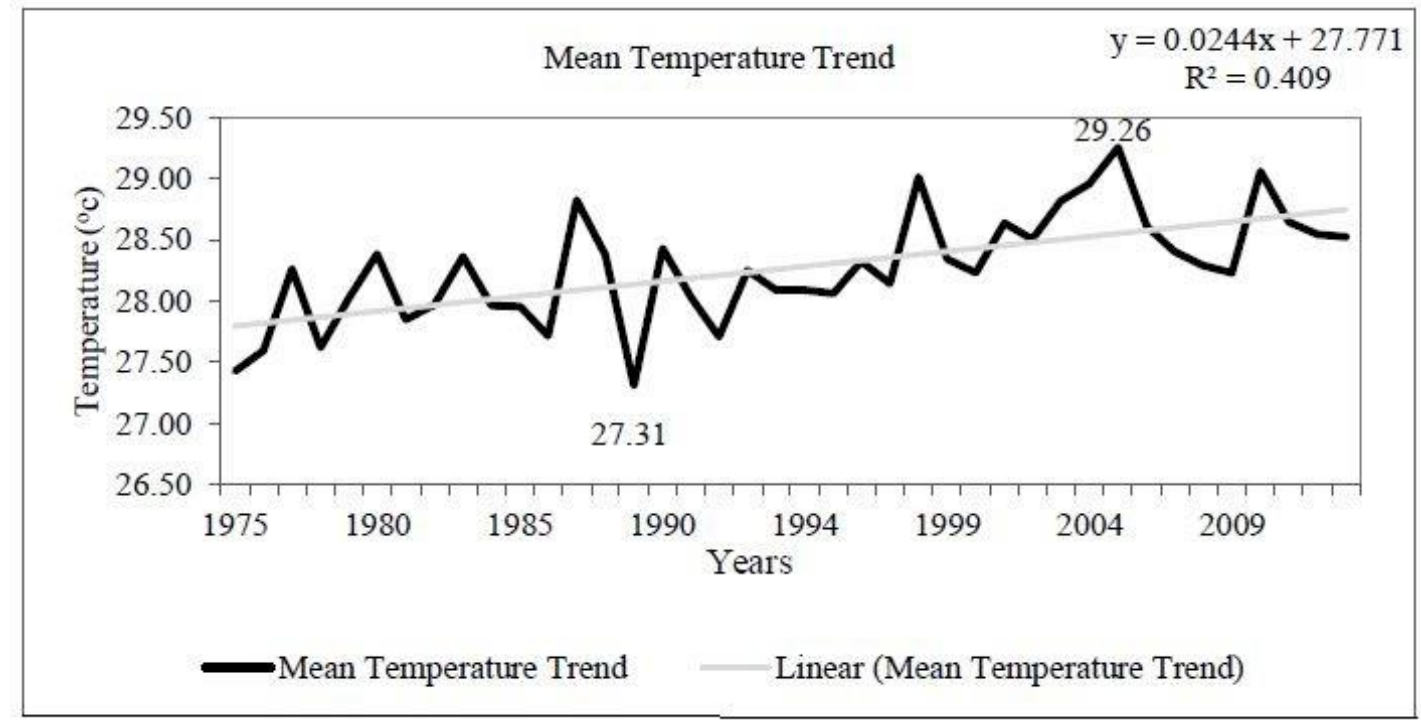

Figure 2: Mean annual temperature trend

Source: Author's data analysis, 2015 
The analysis of figure 3 further showed the characteristics of mean annual temperature over the study period (1975-2014). The period of 1975 to 1997 is characterized to be the cool years with some standardized values below the normal (zero) except years 1980, 1983, 1987, 1990 and 1996. While from 1998 to 2013 mean annual temperature was above the normal. The highest negative standardized value (-2.1) was observed in 1989 while the highest positive standardized value (2.2) was in 2005. The evidence of sudden increase in air temperature in Nigeria was observed as from the early 1970s until 2005 by Bello et al. (2012). This abrupt increase could be linked to the effect of climate change and its associated global warming previously reported in Nigeria by Ikhile, (2007) and supported by the global trend (IPCC, 2007).

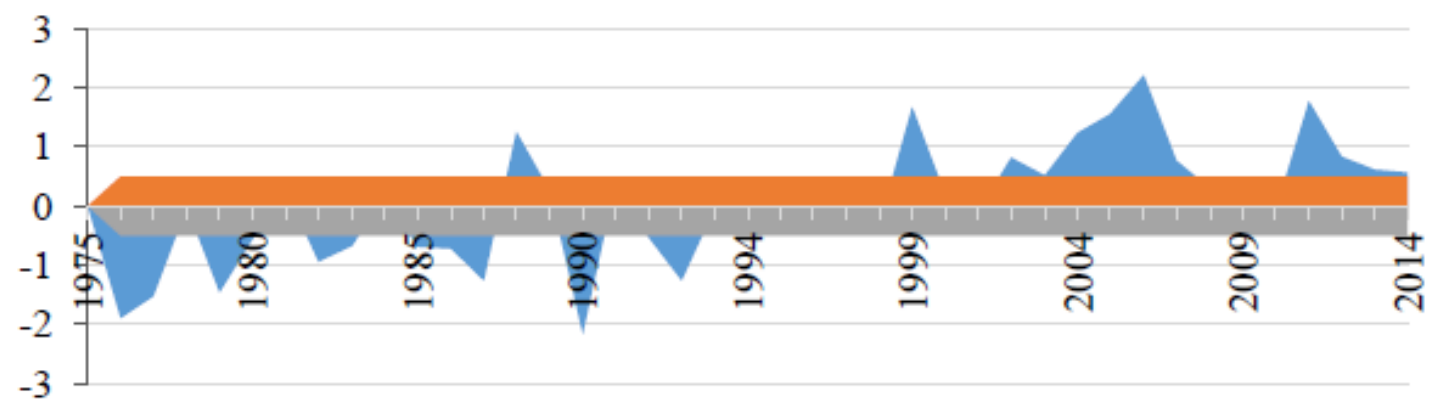

- SA Upper treshold $\quad$ Lower treshold

\section{Figure 3: Annual mean temperature anomaly}

Source: Author's data analysis, 2015

\section{Annual rainfall}

Figure 4 illustrates the average decades of rainfall pattern which showed that in the months of April and October cannot be predictable, that is from 1975 to 2014 and there has been change in term of total rainfall distribution. The Figure 4.8 also reveals that the study area experienced high amount of rain at begins and end of rain season in the last two decades (1995-2014) compare to the first decade (1975-1994). The peak of rain was shifted from August to September for the middle two decade (1985-2004) and has returned to August in last decade (2005-2014). This confirmed Bello et al. (2012) in their studies stating that rainfall was unpredictability and decreasing, which also differ significantly from 1971-2005. Coastal region experiencing slightly 
increasing rainfall since the early 1970s and August break (short-dry-season) is currently being experienced more in July as against August in the Savannah ecology. These evidences show that Nigeria, like most parts of the world, is experiencing the basic features of climate change. However, there is continuous rise in agricultural output from 1987 to 2000 before it dropped in 2001.

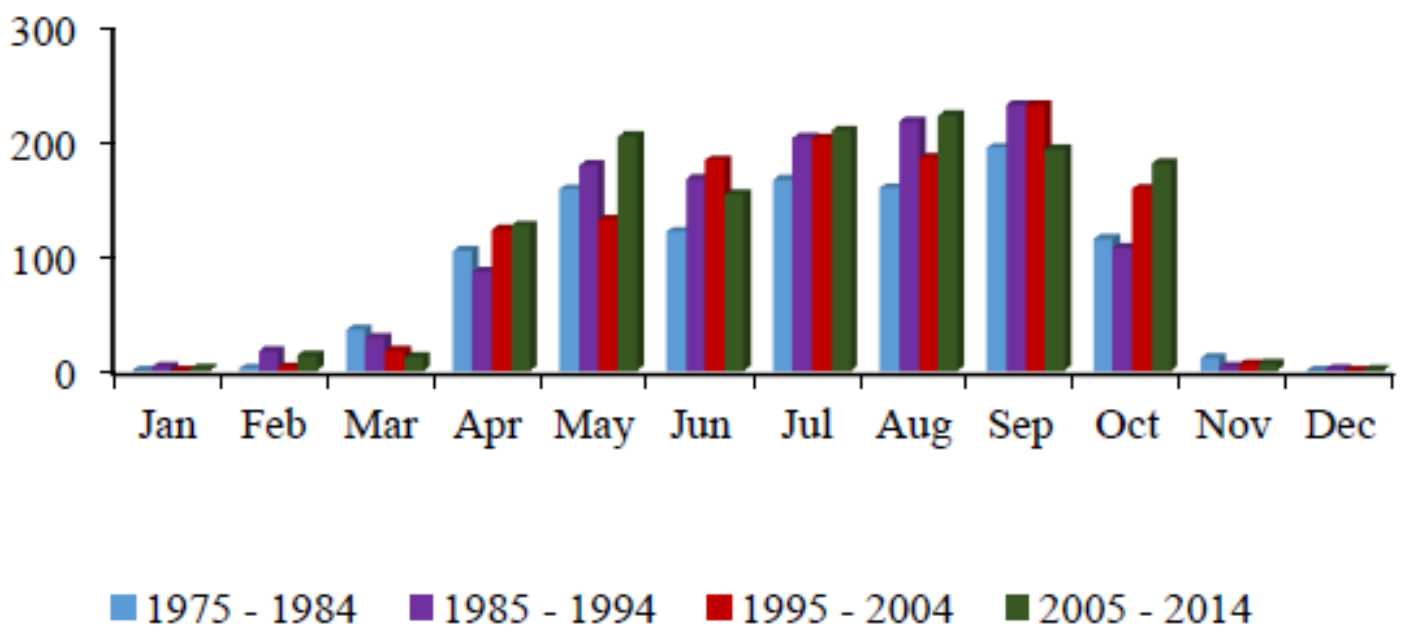

Figure 4: Average decade monthly rainfall trend

Source: Author's data analysis, 2015

The result presented in Figure 5 indicates that there is much variation of rainfall amount from 1975 to 2014.1977 is the year of the lowest amount of rainfall $(771.7 \mathrm{~mm})$ and the starting year of rainfall declined in within the period of the study (1975-2014) though the year 1978 were above the mean. Rain increased between 1986 and 1991 and decreased again between 1992 and 2005 while the highest amount of rainfall was occurred in 1999 (1770.4 mm). The average rainfall is $1218.5 \mathrm{~mm}$ with 243.34 and 0.19 of standard deviation and coefficient of variation respectively. This is in concordance with average rainfall $(1216.86 \mathrm{~mm}$ ) found by Adu (2012) working with thirty (1981-2010) years climatic data of Kogi State. The trend line indicates that the annual rain has increased over the study period and $\mathrm{R}^{2}$ value equal to 0.10 indicates that there is no significant increase in rainfall amount from 1975 to 2014. 


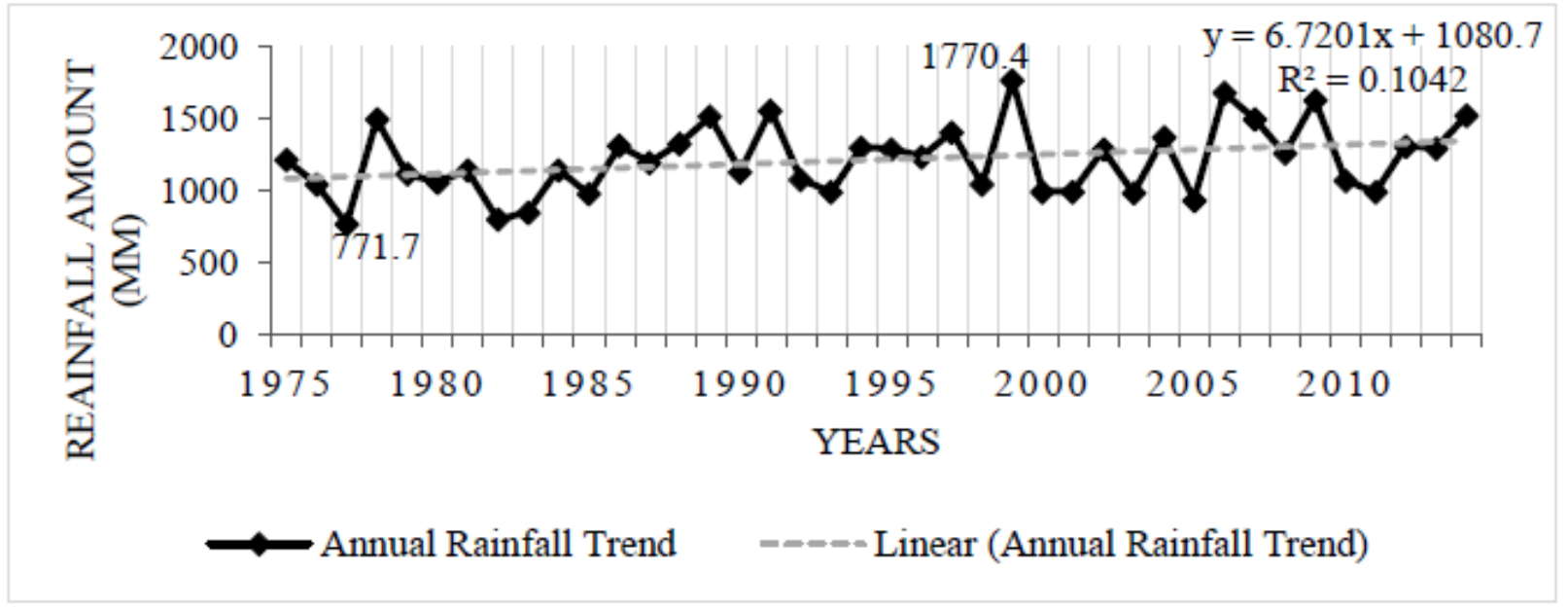

Figure 5: Annual rainfall trend (1975-2014)

Source: Author's data analysis, 2015

Figure 6 presents the annual rainfall anomaly which shows that the study area experienced a successive dryness years from 1975 to 1985 with a wet year occurred in 1978. The period of 1994 to 1997, 2006 to 2009 and 2011 to 2014 were mild and moderate years. Based on the criteria of NIMET standardized precipitation index interpretation, the dryness year was 1977 while the wetness was 1999 with respective standardized value of -1.82 (moderate dryness) and +2.23 (extreme dryness).

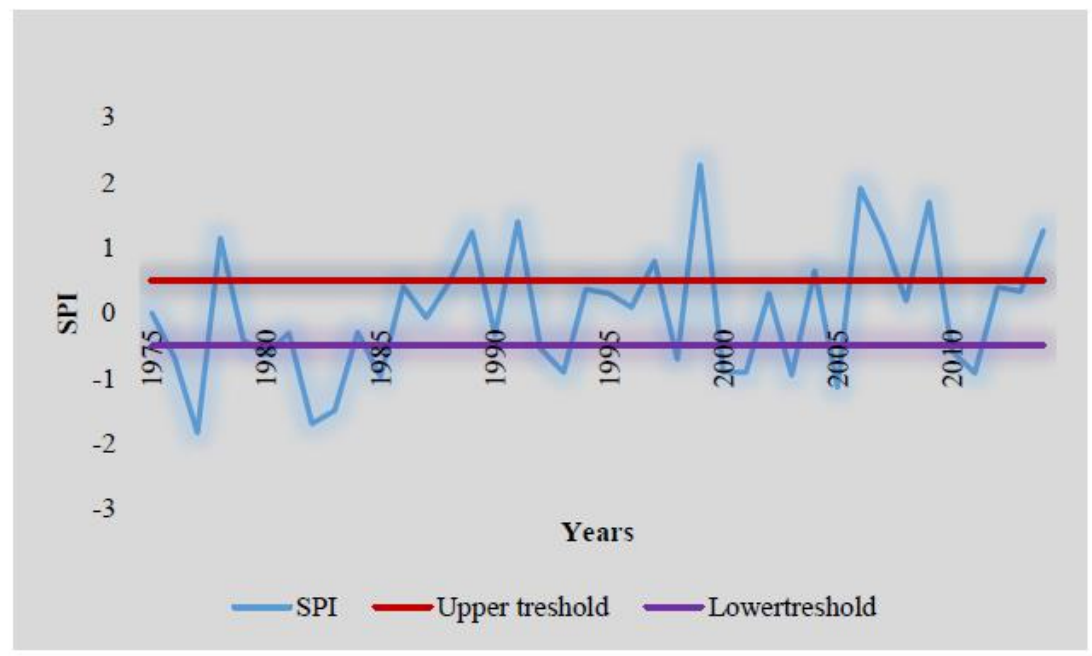

Figure 6: Annual rainfall anomaly

Source: Author's data analysis, 2015 
International Journal of Agriculture and Environmental Research

ISSN: 2455-6939

Volume: 07, Issue: 06 "November-December 2021"

\section{Farmers response of climate change}

\section{Significant change noticed in weather condition over the past forty years}

The result of administrated questionnaire declares that 232 peoples of the respondent out of 240 perceived climate changes and 238 have noticed significant change in weather condition. In Okehi and Adavi local government area $100 \%$ of the respondent have noticed significant change in weather condition. As $97 \%$ of the respondent perceived climate change this implies that most of the farmers in the study area already knew about the concept of climate change. This confirms the assertion of the Southern African Catholic Bishops' Conference (SACBC, 2010) that most Africans are aware that weather and climate patterns are changing but their understanding of global change is limited. Rainfall unpredicted was perceived by the respondent in the three local government areas. The perception of farmers differ from local government area to another, in Adavi local government area only the unpredictable rain was perceived by the respondent. In Ajaokuta local government area increase in rainfall timing and increase in heat were perceived while in Okehi decrease in rainfall timing, increase in rainfall timing and decrease in rainfall timing were perceived by important number of the respondent. As the majority of the farmers interviewed have perceived change in rainfall pattern in the study area; this supports Viglizzo, et al. (2003) that rainfall is the key factors of determining the success of crop production and precipitation changes constrain more than changes in temperature (Challinor et al. 2007).

\section{Farmers' perception of the impact of climate change}

Crop failure was mentioned by the majority of farmers excluding in Ebiya whereby the migration was indicated as the main impact of climate change perceived by the farmers. In Ajaokuta, it has noticed the perception of farmers varies, in addition to crop failure, flooding, human disease outbreaks, livestock, famine and migration were also indicated by a number of respondent as the impact of climate. This indicates that farmers in Ajaokuta are more informed about climate change issue, hence famers in Ajaokuta may be more likely to adopt adjustment strategies against climate change effect than farmers in Adavi and Okehi. Farmers indicated that they have observed changes in rainfall seasons and pattern, temperature are higher in some areas than they were before and incidences of extreme events such as floods and drought have increased. In some areas there are no more rains, and when the rains come it is not at the usual time. In most cases rains delay and this result in crops drying out.

\section{Adaptation strategies in response to climate change}

Seven (7) adaptation strategies were adopted by the farmers (Table 1). Changing planting dates, implement soil conservation schemes and change crop variety were identified as the major adaptation strategies with respective percentages of the respondents $31 \%, 22 \%$ and $21 \%$ in 
response to change in rainfall. This implies that farmers in the study area are noticing the variation in climatic variables and have adopted various adaptation options to counteract the negative impact of climate change in the area. Similar results were found by Fosu-Mensah et al. (2010) whereby shifting the planting date being the most important adaptation measure. Kurukulasurya and Rosental (2003) noted that the short-term adaptation measures for climate change by farmers include crop insurance for risk coverage, crop/livestock diversification to increase productivity and protection against diseases, adjusting the timing of farm operations to reduce risks of crop damage, change crop intensity and adjust livestock management to new climatic conditions, food reserves and storage as temporary relief, changing cropping mix, permanent migration to diversify income opportunities, defining land use and tenure rights for investments. On a long term note, the authors stated the following as best adaptation options for climate change: development of crop and livestock technology adapted to climate change stress, develop market efficiency, irrigation and water storage expansion, efficient water use, promoting international trade, improving forecasting mechanisms, institutional strengthening and decisionmaking structures.

Table 1: Adaptation measures adopted

\begin{tabular}{lll}
\hline Adaptation measures & Total & $\%$ \\
\hline Change crop variety & 146 & 21.82 \\
$\begin{array}{l}\text { Build water harvesting } \\
\text { schemes }\end{array}$ & 8 & 1.195 \\
$\begin{array}{l}\text { Implement soil conservation } \\
\text { schemes }\end{array}$ & 152 & 22.72 \\
$\begin{array}{l}\text { Diversification of crop types } \\
\text { and varieties }\end{array}$ & 22 & 3.28 \\
$\begin{array}{l}\text { Changing planting dates } \\
\text { Changing size of land under } \\
\text { cultivation }\end{array}$ & 211 & 31.53 \\
Irrigation & 6 & 18.53 \\
\hline
\end{tabular}

Source: Field survey, 2015

\section{Constraints to adopt adaptation strategies}

Greater proportion of farmers (85\%) identified lack of capital as major constraint. This could be attributed to high cost of adaptation options. Inadequate fund hinders farmers from getting the necessary resources and technologies which assist to adapt successfully to climate change. Deressa et al. (2008) reported that adaptation options are costly. Hence if farmers do not have sufficient family labour or the financial means to hire labour, they cannot adapt. $9 \%$ of the 


\section{International Journal of Agriculture and Environmental Research}

ISSN: 2455-6939

Volume: 07, Issue: 06 "November-December 2021"

farmers in the study area complained of lack of information as constraint to climate change adaptation options. This could be attributed to dearth in research on climate change as well as poor information dissemination on the part of the government information agencies, thus, information is lacking in this area. Others 3 and $2 \%$ of the farmers in the study area complained shortage of labour and poor health respectively, which could be attributed to non-availability of family labour and also attributed to poor health insurance. Ultimately, there is no doubt that these barriers are responsible for poor adaptation to climate change by the farmers as well as poor resource use efficiency and poor output recorded in the area. Fighting these problems will be vital in promoting not just local adaptation option but global modern adaptation practices/options to climate change in the area and beyond.

\section{Factors determining farmers' decision to change farm size}

The result of logit model was globally significant (-2log-likelihood $=239.09 ; \mathrm{R}^{2}$ of Cox \& Snell $=0.30 ; R^{2}$ of Nagelkerke $\left.=0.41\right)$ with a good prediction $\left(R^{2}=75.3 \%\right)$. The coefficients were also globally significant (Test of Omnibus; Chi square $=86.34 ; \mathrm{P}<0.001$ ). The household decision to change the land under cultivation was significantly influenced by the number of family member schooling, household farming experience and access to credit. The coefficient was negative with family member schooling suggesting that the higher the family member schooling the lower the probability of household to increase the farm size. Regarding the farming experience and access to credit the coefficients were positive (see Table 2). This would indicate that the decision to increase the farm size increase when the household access to credit and farming experience increased.

Though change in rainfall negatively influenced the decision of household to change land under cultivation but it not significant. Such a relationship should not be surprising as empirical evidence from elsewhere that increase in the amount of rainfall translated into decrease in arable land usage (Kori et al., 2012). This reinforces the observations by IPCC (2007) and Allamano (2010) that climate change in West Africa will result in negative impacts on agriculture. This, by extension, poses serious food insecurity problems to farmers who rely on rain fed agriculture. 
International Journal of Agriculture and Environmental Research

ISSN: 2455-6939

Volume: 07, Issue: 06 "November-December 2021"

Table 2: Factors determining farmers' decision to change land use under cultivation

\begin{tabular}{lllll}
\hline Variables & Coefficients & Standard Error & Wald $\mathrm{x}^{2}$ test & P-value \\
\hline village & 0.041 & 0.128 & 0.104 & 0.747 \\
Sex & -0.290 & 0.506 & 0.329 & 0.566 \\
Age & 0.422 & 0.351 & 1.447 & 0.229 \\
Level of education & -0.100 & 0.098 & 1.054 & 0 \\
& & & & .305 \\
Marital status & -0.500 & 0.844 & 0.351 & 0.553 \\
Family members & 0.561 & 0.352 & 2.532 & 0.112 \\
FMS & $-1.131^{*}$ & 0.445 & 6.467 & 0.011 \\
FMIFA & 0.106 & 0.460 & 0.053 & 0.818 \\
EA & 0.434 & 0.367 & 1.401 & 0.237 \\
Social group & 0.324 & 0.348 & 0.865 & 0.352 \\
Farming experience & $1.433 * *$ & 0.290 & 24.440 & 0.000 \\
Land tenure & 0.129 & 0.118 & 1.189 & 0.276 \\
Extension service & 0.458 & 0.544 & 0.710 & 0.400 \\
Access to credit & $1.359^{* *}$ & 0.376 & 13.082 & 0.000 \\
Access to market & -0.071 & 0.057 & 1.560 & 0.212 \\
Change in rainfall & -0.064 & 0.194 & 0.108 & 0.743 \\
Soil fertility & 0.750 & 0.484 & 2.397 & 0.122 \\
Constant & -6.383 & 2.634 & 5.872 & 0.015 \\
\hline
\end{tabular}

Source: Author's data analysis

\section{CONCLUSION}

This study aimed at assessing the impact of climate change on agricultural land use in Kogi State using forty years (1987-2014) rainfall and temperature and administrated questionnaire to achieve the three specific objectives. Analyze of climate data that the mean annual temperature has increased from 27.43oc to 28.53 oc between 1975 and 2014 in the study area (Kogi State). Lowest and highest temperature were recorded in 1989 and 2005. The period of 1975 to 1997 is characterized has the cool years as the values were below the normal (zero) expect years 1980, 1983, 1987, 1990 and 1996. While from 1998 to 2013 mean annual temperature was above the normal. Average rainfall is $1218.5 \mathrm{~mm}$. The rain season is from April to October as high amount of rainfall are concentrated within this eight (8) months of the years in the study area. The pattern of rainfall in the months of April and October has been very unpredictable from 1975 to 2014. The study area experienced high amount of rain at begins and end of rain season in the last two decades (1995-2014) compared to the first decade (1975-1994). The peak of rain was shifted from August to September for the middle two decade (1985-2004) and has returned to August in 


\section{International Journal of Agriculture and Environmental Research}

ISSN: 2455-6939

Volume: 07, Issue: 06 "November-December 2021"

last decade (2005-2014). The trend line indicates slight increase in rainfall over the study period from 1975 to 2014 the dryness year was 1977 while the wetness was 1999 with respective standardized value of -1.82 (moderate dryness) and +2.23 (extreme dryness). In a nutshell, we can say that though, the study area is experience more war there but rainfall is increasing which confirms global warming in the study area.

Farmers interviewed claimed an increase in land under crop. The total land under crop were 993.50 ha before 2010 and is actually 1029 ha. Land tenure system is based on four land tenure system as stated by the farmers namely inherited land $52.8 \%$, rented land $20.4 \%$ and communal $27.08 \%$. Manual tillage has been the most common land management practices adopt in the study, $60 \%$ of the respondent in the last thirty years and $67.92 \%$ between 2010 and 2014. Now important number of farmers has abandoned burning land, only $4.58 \%$ in the last thirty years compared to $18.33 \%$ between 2010 and 2014. Sifting cultivation was one of the frequently used for maintaining soil fertility. Recently increasing population has driven farmers to abandon shifting cultivation resulting in the use of fertilizers to maintain soil fertility up to $79 \%$ of the respondents though, important of the respondent stated the difficulty to access fertilizers. The minimum and maximum farm size under crop were between 0.5 ha and 8 ha and has increased from 1 ha to 10 ha. But the majority of farm size are 2 to 5 ha either in last thirty years or present.

Changing planting dates, implement soil conservation schemes and change crop variety were identified as the major adaptation strategies in response to change in rainfall. Lack of capital as major constraint. Logit regression analysis reveals that climate change (rainfall) has no significant impact on farmers' decision to change land use under cultivation while number of family member schooling, household farming experience and access to credit have significant impact. Though change in rainfall negatively influenced the decision of household to change land under cultivation but it not significant.

\section{RECOMMENDATION}

As demonstrated in this study, farmers are well aware about the climate change and its impact on their livelihood but limited to adopt adaptation strategies. Therefore, based on findings from the study, as a recommendation, respondents argued that they need more education on how to deal with climatic changes and if possible, the government could help with machinery and other farming equipment. In addition, they also requested the provision of loans, to assist them diversify their economic activities in other sectors as climate changes affects farm and livestock products. 


\section{International Journal of Agriculture and Environmental Research}

ISSN: 2455-6939

Volume: 07, Issue: 06 "November-December 2021"

The climate changes and variations have always been occurring and in recent years the change has been happening at a higher rate than observed before. These changes are predicted to continue at an even higher rate in future. With $80 \%$ of Kogi State depending on agriculture for survival there is urgent need to explore various copping strategies, safety nets and policies that will prevent farmers falling into poverty due to lack of food and income from agriculture activities and livestock products. There is also a need of having consistent strategies and improved institutional capacity and planning within different ministries and other stakeholders to address different challenges farmers face due to climate change.

Further research should look at the rainfall pattern (onset, cessation, rainfall timing) in the study area for better agricultural planning.

The following measures should also adopt in order to minimize the adverse effect of current climate events:

- Conservation crop rotation and alley cropping are effective land management practices in response to climate change, this should be advice to the farmers in the study area.

- Furthermore, improving the knowledge and skills of extension service personnel about climate change and making the extension services more accessible to farmers appear to be the key components to rise farmer's adaptation capacity to climate change.

- Enhanced farmers' access to affordable credit will increase their ability to adopt sustainable agricultural land use in response to climate change.

\section{ACKNOWLEDGEMENT}

Deep gratitude goes to the West African Science of Climate Change and Adapted Land Use (WASCAL) program for sponsoring this study.

\section{REFERENCES}

[1] Ahenkan, A. \& Boon E. (2010). Climate Change Adaptation through Sustainable Forest Management: A Case Study of Communities around the Sui River Forest Reserve, Ghana; 18th Common wealth Forestry Conference.

[2] Aigbokhan, B. E. (2001). Resuscitating Agricultural Production (Cocoa, Cotton, Groundnuts, Palm oil, Rubber etc) for exports. Paper Presented at the 10th Annual Conference of Zonal Research Units of the Central Bank of Nigeria, 4 - 8 June, 2011. Retrieved on December, 13th 2014 from http://www.cenbank.org/out/publications/occasionalpapers/rd/2014we01-6pdf

[3] Allamano, P., Claps, P. \& Laio, F. (2010). Global Warming Increases Flood Risk in Mountain Areas. Geophysical Research Letters. 
International Journal of Agriculture and Environmental Research

ISSN: 2455-6939

Volume: 07, Issue: 06 "November-December 2021"

[4] Apata T. G., Samuel, K. D. \& Adeola, A. O. (2009). Contributed Paper prepared for presentation at the International Association of Agricultural Economists' 2009 Conference, Beijing, China, August 16-22, 209

[5] Audu, E.B. (2012). A Descriptive Analysis of Rainfall for Agricultural Planning in Lokoja Local Government Area of Kogi State, Nigeria. International Journal of Science and Technology. ISSN 2224-3577.

[6] Bello, O. B., Ganiyu O. T., Wahab, M. K. A., Afolabi, M. S., Oluleye, F., Ig S. A., Mahmud J.,... \& Abdulmaliq S. Y. (2012). Evidence of Climate Change Impacts on Agriculture and Food Security in Nigeria. International Journal of Agriculture and Forestry 2012, 2(2): 49-55 DOI: 10.5923/j.ijaf.20120202.08 DOI: 10.5923/j.ijaf.20120202.08

[7] Challinor, A., Wheeler, T., Garforth, C., Craufurd, P. \& Kassam, A. (2007). Assessing the vulnerability of food crop systems in Africa to climate change. Climatic Change 83(3):381-399.

[8] Deressa, T., Hassan, R. M., Alemu, T., Yesuf, M. \& Ringler, C. (2008). Analyzing the Determinants of Farmers' Choice of Adaptation Methods and Perceptions of Climate Change in the Nile Basin of Ethiopia. IFPRI Discussion Paper 00798.

[9] Fischer, G., Shah, M. \& Velthuizen, H. V. (2002) "Climate Change and Agricultural Vulnerability". International Institute for Applied Systems Analysis. Report prepared under UN Institutional Contract Agreement 1113 for World Summit on Sustainable Development. Laxenburg, Austria.

[10] Fosu-Mensah, B. Y., Vlek, P. L. G. \& Manschadi, A. M. (2010). Farmers' Perception and Adaptation to Climate Change; A Case Study of Sekyedumase District in Ghana. Center for Development Research (ZEF), University of Bonn, Walter-Flex-Str. 3, 53113, Bonn, Germany.

[11] Ibitoye, S. J. (2006). The Impact of Cooperative Societies on Rural Development in Ankpa LGA of Kogi State, Nigeria. National Association of Science, Humanities and Education Research Journal (NASHERJ). 4 (2): 193-198.

[12] IPCC. (2007) Summary for Policymakers. In: Climate Change 2007: Impacts, adaptation and vulnerability. Contribution of Working Group II to the Fourth Assessment Report of the Intergovernmental Panel on Climate Change,

[13] Kori, E., Gondo, T. \& Madilonga, R. (2012). The Influence of Rainfall Variability on Arable Land Use at Local Level: Realities from Nzhelele Valley, South Africa. International Conference on Future Environment and Energy IPCBEE vol.28 (2012) () (2012) IACSIT Press, Singapore. 
International Journal of Agriculture and Environmental Research

ISSN: 2455-6939

Volume: 07, Issue: 06 "November-December 2021"

[14] Kurukulasuriya, P, \& Rosenthal, S. 2003. Climate change and agriculture: A review of impacts and adaptations. Paper No. 91 in Climate Change Series, Agriculture and Rural Development Department and Environment Department, World Bank, Washington, DC.

[15] Lobell, D. B., Burke, M. B., Tebaldi, C., Mastrandrea, M. D., Falcon, W. P. \& Naylor, R. L. (2008). "Prioritizing climate change adaptation needs for food security in 2030". Science 319 (5863): 607-10

[16] McCalla, A F (1998).'Agriculture and Food Needs to 2025' in 'International Agricultural Development' edited by Carl K. Eicher and John M. Staatz, Johns Hopkins University.Press

[17] Molua E L., (2002). Climate variability, vulnerability and effectiveness of farm-level adaptation options: the challenges and implications for food security in Southwestern Cameroon; Environment and Development Economics 7: 529-545

[18] NBS (National Bureau of Statistics). (2006). Annual Abstracts of Statistics of Nigeria.

[19] Ngaira, W. J. K. (2007). Impact of Climate Change on Agriculture in Africa by 2030. Academic Journals 1992-2248.

[20] Nyamadzawo G, Wuta M, Nyamangara J, Gumbo D. (2013). Opportunities for optimization of in-field water harvesting to cope with changing climate in semi -arid smallholder farming areas of Zimbabwe; Springerplus. 2013 December; 2(1): 100.

[21] Odoemelam, U. B. (2011) 'Rural Agricultures and Sustainable Employment Generation in Nigeria", KOGJOURN: An International Journal of Sociology, Vol.1, No.2:1-10

[22] OECD (2009). Climate Change in West Africa: Sahelian Adaptation Strategies; SWAC

[23] Oksen, P (2000). Cattle, conflict and change: animal husbandry and Fulani -farmer's interaction in Boulgou Province, Burkina Faso. Ph.D Thesis, Roskilde University, Denmark.

[24] Olagunju, E. G. (2007). Water Resources Development: Opportunities for Increased Agricultural Production in Nigeria. Retrieved on December 12, 2014 from www. google.com.

[25] Olagunju, E. G. (2007). Water Resources Development: Opportunities for Increased Agricultural Production in Nigeria. Retrieved on December 12, 2014 from www. google.com.

[26] Onyeahialam,V. (2002). Administration of Agricultural Development Programme Towards Socio -Economic Development of Nigeria. Journal of Policy and Development Studies,Vo1.1 No.2:15-23

[27] SACBC (Southern African Catholic Bishops' Conference). (2010). South African's awareness of climate change. Brief Paper 235. Parliamentary Liason Office. http://www.cplo.org.za. Retrieved on September 6, 2014.th

[28] Spore (2008). Climate change. Special Issue, pp 23. 
International Journal of Agriculture and Environmental Research

ISSN: 2455-6939

Volume: 07, Issue: 06 "November-December 2021"

[29] Uchua, K. A (2011). Mapping and Analysis of Agricultural Systems in a part of the Lower

[30] Viglizzo, E. F., Pordomingo, A. J., Castro M. G. \& Lertora F. A. (2003) Environmental Assessment of Agriculture at a Regional Scale in the Pampas of Argentina. INTA/CONICET, Centro Regional La Pampa, La Pampa, Argentina

[31] World Bank. (2008). World Bank development report: Agriculture for development. Washington DC. 